\title{
Phillipsia olivacea: an uncommon Neotropical discomycete discovered in the Brazilian semiarid
}

\author{
Lopes-Lima AB, Valões-Araújo JC and Wartchow F
}

Universidade Federal da Paraíba, Departamento de Sistemática e Ecologia/CCEN, CEP: 58051-970, João Pessoa, $P B, B R A Z I L$.

Lopes-Lima AB, Valões-Araújo JC, Wartchow F 2019 - Phillipsia olivacea: an uncommon Neotropical discomycete discovered in the Brazilian semiarid. Studies in Fungi 4(1), 21-25, Doi $10.5943 / \mathrm{sif} / 4 / 1 / 3$

\begin{abstract}
Phillipsia olivacea is an uncommon discomycete record from Brazil. It was described originally from South Brazil and later recorded from Central America and northern South America. Now it is found for the first time from a montane forest in the Brazilian semiarid region. Description, discussion, photography of the ascomata and drawings are provided.
\end{abstract}

Key words - Ascomycota - Neotropic - Pezizomycetes - Sarcoscyphaceae - taxonomy

\section{Introduction}

Phillipsia Berk. is a genus with at least 17 known species from Central and South America, Africa, Asia and Australia (Ekanayaka et al. 2017). In the protologue, it was described with thick and firm context, wide cupuliform-discoid cupule and hymenium always opened, and included six species previously included in Peziza (Berkeley 1881). The most comprehensive studies about the Phillipsia were performed by Denison (1969), Hansen et al. (1999) and more recently Ekanayaka et al. (2017), who defined to this genus all the discomycetes with bright colored apothecia that frequently grow in dead woods, the suboperculate asci and the thin and poorly differentiated outer exipulum from the medullary exipulum.

Some species are reported or described from Africa and Asia (e.g., Kalchbrenner \& Cooke 1880, Moravek 1997, Zhuang 2003, Wang 2012, Ekanayaka et al. 2017). In Neotropic the following taxa are known: P. carminea (Pat.) Le Gal, P. costaricensis Denison, P. crispata (Berk. \& M.A. Curtis) Le Gal, P. domingensis (Berk.) Berk., P. lutea Denison, P. gigantea Seaver, $P$. guatemalensis Paden and P. olivacea (Rick 1931, Seaver 1942, Denison 1969, Paden 1977, Hansen et al. 1999, Calonge et al. 2006, Angelini \& Medardi 2012, Oliveira et al. 2013).

Continuing studies on macrofungi from the State of Paraíba, Brazil, an interesting discomycete was discovered in a montane forest ('brejo de altitude') from the Brazilian semi arid region that corresponds a new finding to Caatinga biome.

\section{Materials \& Methods}

Phillipsia ascomata were collected in a 'brejo de altitude' forest called Mata do Pau-Ferro. The characterization of the area was already summarized by Sá \& Wartchow (2016). Microscopic observations were made from material mounted in $3 \% \mathrm{KOH}$, Congo red solution and Melzer's reagent. The material is deposited at JPB (Thiers, continuously updated). 


\section{Results}

Phillipsia olivacea Rick, Brotéria, Ser. Bot. 26: 357. 1931.

Figs $1-5$

Facesoffungi number: FoF05770

Apothecia up to $25 \mathrm{~mm}$ in diam., $10 \mathrm{~mm}$ high when fresh, sub-stipitate with short stipe about $5 \mathrm{~mm}$ long and $2 \mathrm{~mm}$ wide, shallowly cup shape to disc-shaped, uniformly greenish-olivaceous then brownish in dried state, receptacle convex, lower side dirty white to creamy when fresh, coriaceous but more tougher in dried state.

Ascospores (26-) 26.5-32.5 (-33.2) × (8.2-) 9.2-12.8 (-13.3) $\mu \mathrm{m}(x=28.8 \times 11.2 \mu \mathrm{m}, \mathrm{n}=$ 30), uniseriate, ellipsoidal to reniform, with rounded or slightly apiculate apices, guttulate, hyaline, thin walled, smooth in MO. Asci 215-275 × 11-16 $(-21) \mu \mathrm{m}(x=232 \times 14 \mu \mathrm{m}, \mathrm{n}=20)$, long stipitate, cylindrical, colorless, suboperculate, 8-spored. Paraphyses 2.4-4.6 $\mu \mathrm{m}(x=3.4 \mu \mathrm{m}, \mathrm{n}=$ 20) wide, abundant among the asci, filiform, septate, sometimes with orange granules. Subhymenium composed of gelatinized cells of textura intricata with interwoven hyphae 4-6 $\mu \mathrm{m}$ wide. Ectal excipulum 90-150 $\mu \mathrm{m}$ thick at lower flanks, composed of loosely arranged cells of textura prismatica with hyphae 5-15 $\mu \mathrm{m}$ wide. Medullary excipulum $0.5-1 \mathrm{~mm}$ thick, composed of plentiful, intensely interwoven arranged thin-walled hyphae of textura intricata 4-7 $\mu \mathrm{m}$ wide.

Known distribution - Brazil (Rio Grande do Sul, Paraíba, Paraná and Santa Catarina), Costa Rica, Ecuador and Venezuela.

Habit - on rotten wood in a montane forest in the Brazilian semiarid.

Material examined - Brazil, Paraíba, Areia, Parque Estadual Mata do Pau-Ferro, Trilha do Cumbe, 17 July 2017, F. Wartchow 60/2013 (JPB 63853).

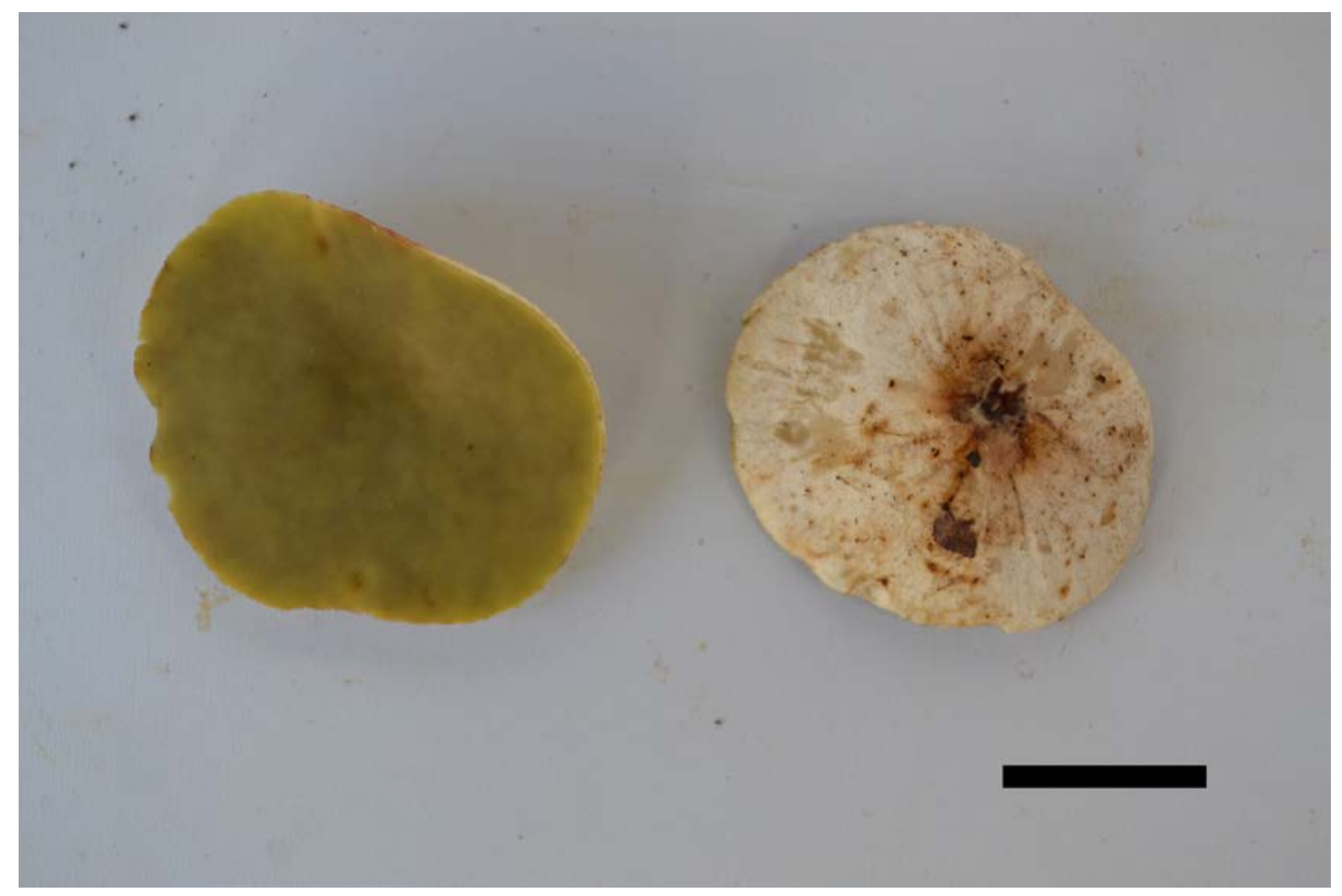

Fig 1 - Phillipsia olivacea. 1 Apotecia. Scale Bar = $10 \mathrm{~mm}$.

\section{Discussion}

Phillipsia olivacea is characterized macroscopically by the small, cupulate to discoid apothecia, sometimes bearing small stipe, and the greenish olivaceous hymenium. Microscopically, the 8-spored asci and the elliptic reniform ascospores lacking striations and smooth under light microscope measuring (26-) 26.5-32.5 (-33.2) × (8.2-) 9.2-12.8 (-13.3) $\mu \mathrm{m}$ also help to characterize the species. Two microscopic features we need attention: the smaller asci and the ascospore surface. Regarding to smooth basidiospore wall observed here, it corroborates with 
Hansen et al. (1999: 307) on which they are reported as smooth under light microscope. The most interesting surprise was regarded in the size of the asci. Hansen et al. (1999: 306) reported longer ones $400-480 \times 14-16 \mu \mathrm{m}$ in the lectotype of $P$. olivacea analysed by them. On the other hand our collection presented only 215-275 $\times 11-16(-21) \mu \mathrm{m}$. During examination we found many asci which did not release their ascosporos. We suspect that the shorter asci in our collection is due the material was not sufficiently mature. We need explain here that we measured the asci from the very base of the structure. Thus, although the shorter asci, all other features of our collection agree with P. olivacea described by Hansen et al. (1999) and Calonge et al. (2006).

Originally known from Rio Grande do Sul, South Brazil (Rick 1931), it was later reported from Paraná and Santa Catarina, and also Costa Rica, Ecuador and Venezuela (Denison 1969, Hansen et al. 1999, Calonge et al. 2006).
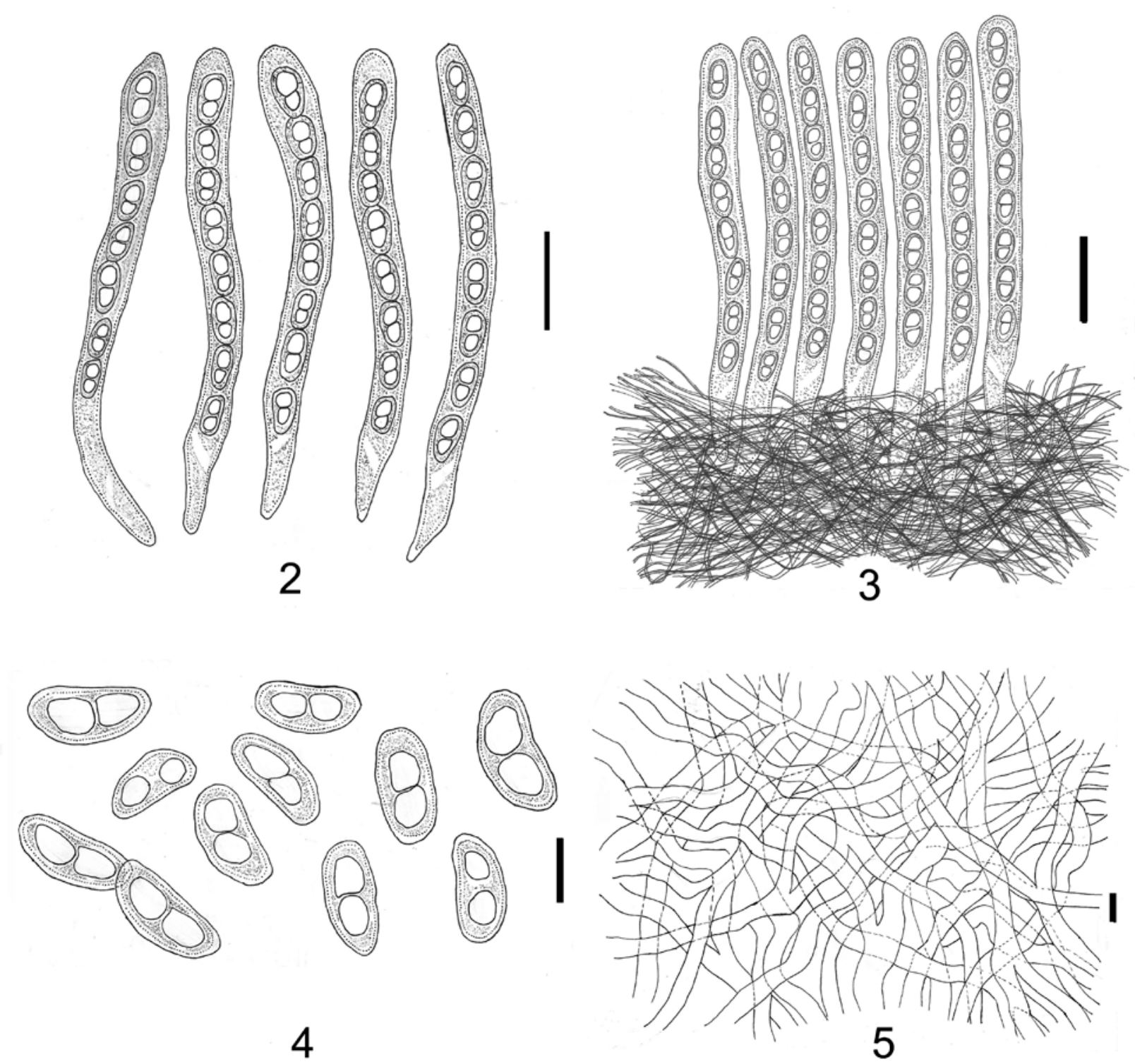

Figs 2-5 - Phillipsia olivacea. 2 Asci. 3 Asci and the subhymenial hyphae of the textura intricata. 4 Ascospores. 5 Hyphae of the textura intrincata of the medullary excipulum. Scale Bars $=10 \mu \mathrm{m}$.

The discovery of $P$. rugosospora by Paden (1977) from Costa Rica was referred with yellow hymenium, but later synonymized with P. olivacea by Hansen et al. (1999) who extended the description of the species for the ones with yellow, dull orange and light brown hymenium. 
Calonge et al. (2006) rediscovered the species from Costa Rica and cited the hymenium with variable color, from greenish yellow, grayish green, olive green then dark green.

Differently from $P$. olivacea, other species can be easily separated by the apotecial hymenium color. Ekanayaka et al. (2017) provided a complete table of 17 species of Phllipsia known to date. However, all other species have distant hymenium color as pink (e.g., P. hartmannii), coral red [e.g., P. umbilicata (Penz. \& Sacc.) Boedjin], orange [e.g., P. crenulata (Sacc.) Le Gal], rosaceous tan (e.g., P. guatemalensis Paden), tan (e.g., P. costaricensis Denison) or even white (e.g., $P$. ranomafanensis J. Moravec). In addition, although other collections of P. olivacea varying from pale yellow to olive brown, the non-striate and smooth ascosporos (smooth to wrinkled under SEM according to Hansen et al. 1999: 307) are distinguished (Hansen et al. 1999).

\section{Acknowledgements}

The project is supported by the 'Conselho Nacional de Desenvolvimento Científico e Tecnológico' (CNPq) with the Projects 'Programa de Pesquisa em Biodiversidade' (PPBio Proc. 60/2009), 'Fungos agaricoides em áreas de Mata Atlântica e Caatinga no Estado da Paraíba' (Edital Universal Proc.. 420.448/2016-0), 'Produtividade em Pesquisa' (Proc. 307922/2014-6) grant for FW, 'Iniciação Científica' - IC (Proc. 307947/2017-3) scholarship to JCVA. PIBIC-UFPB (IC), with the Project PVA785-2018 - 'Revisão e ampliação do acervo de fungos do herbário JPB' (Edital 01/2018/PROPESQ Seleção de Projetos de Iniciação Científica 2018/2019) is also acknowledged for providing scholarship to ABLL.

\section{References}

Angelini C, Medardi G. 2012 - Tropical fungi: twelve species of lignicolous Ascomycota from the Dominican Republic. Mycosphere 3, 567-601.

Berkeley MJ. 1881 - Australian Fungi II. Received principally from Baron F. Von Mueller. Botanical Journal of the Linnean Society 18, 383-389.

Calonge FD, Mata M, Umaña L. 2006 - El género Phillipsia (Ascomycota) en Costa Rica, con una clave para identificar las espécies. Boletín de la Sociedad Micológica de Madrid 30: 35-42.

Denison WC. 1969 - Central Americam pezizales III. The genus Phillipsia. Mycologia 61, 289304.

Ekanayaka AH, Bhat DJ, Hyde KD, Jones EBG, Zhao Q. 2017 - The genus Phillipsia from China and Thailand. Phytotaxa 316, 138-148.

Hansen K, Pfister DH, Hibbett DS. 1999 - Phylogenetic relationships among species of Phillipsia inferred from molecular and morphoplogical data. Mycologia 91, 299-314.

Kalchbrenner C, Cooke MC. 1880 - South African Fungi. Grevillea 9, 17-34.

Moravek J. 1997 - Discomycetes of Madagascar I. Phillipsia ranomafanensis sp. nov. and ascospore sculpture of Cookeina colensoi proved by SEM (Discomycetes, Pezizales, Sarcoscyphaceae). Czech Mycology 50, 21-33.

Oliveira BF, Bezerra JL, Santos NV. 2013 - Primeiro registro de Cookeina sulcipes, C. tricholoma e Phillipsia domingensis no Bioma Mata Atlântica do Sudeste da Bahia. Agrotrópica 25, 3944.

Paden JW. 1977 - Two new species of Phillipsia from Central America. Canadian Journal of Botany 55, 2685-2692.

Rick J. 1931 - Monographia pezizinearum riograndensium. Brotéria Série Botânica 25, 77-98.

Sá MCA, Wartchow F. 2016 - Volvariella leucocalix (Pluteaceae), a new species from Brazilian semiarid region. Mycosphere 7, 30-35.

Seaver FJ. 1942 - The North American Cup-Fungi (Operculates). Published by the author, New York.

Thiers B. [continuously updated] - Index Herbariorum: A global directory of public herbaria and associated staff. - New York Botanical Garden's Virtual Herbarium. http://sweetgum.nybg.org/ih/ (accessed 21 November 2018) 
Wang YZ. 2012 - The genus Phillipsia in Taiwan. Taiwania 57, 322-326.

Zhuang W-Y. 2003 - Re-dispositions of Phillipsia (Pezizales) collections from China. Mycotaxon 86, 291-301. 